\title{
Assessing the Roles of Mosques in Enhancing the Islamic Economic Practices
}

\author{
Mochammad Arif Budiman \\ Prodi Akuntansi Lembaga Keuangan Syariah (ALKS) \\ Politeknik Negeri Banjarmasin \\ Banjarmasin, Indonesia \\ E-mail: m.arif.budiman@poliban.ac.id
}

\author{
Manik Mutiara Sadewa \\ Prodi Akuntansi Lembaga Keuangan Syariah (ALKS) \\ Politeknik Negeri Banjarmasin \\ Banjarmasin, Indonesi
}

\begin{abstract}
A mosque is a sacred place in Islam that has a central role for the community. It is argued that the mosque can potentially provide necessary supports to enhance the Islamic economic practices. Therefore, this study explores to what extent mosques in Banjarmasin, Indonesia, play their roles in enhancing the Islamic economic practices in the city. The data were collected through a survey using purposive sampling technique in which the board of management and the community of the mosques were selected to be the respondents. The findings indicate that in general, the mosques in Banjarmasin have not yet played a significant role in enhancing the Islamic economic practices. This can be seen from the lack of understanding on some Islamic economics concepts especially about the legal status of interest (bunga bank) and terms used in the industry, the low level of synergy and cooperation between the mosques and Islamic banking industry, and the minimum frequency of learning and training about Islamic economics concept delivered in the mosques. This study contributes to knowledge by presenting the existing role of mosques in relation with Islamic economic practices which provides useful information for further studies.
\end{abstract}

Keywords-mosque; Islamic economic practices; Islamic bank; synergy; cooperation

\section{INTRODUCTION}

The existence of a mosque in the Muslim community is necessary. In addition to being a place for ritual worship, a mosque has essentially many roles and functions for Muslim society. However, the roles of mosques in the current times are apparently more concentrated on the ritualistic and educative ones [1], while other important roles such as social, politic, and economic, are commonly ignored. More specifically, the roles of mosques for developing the Islamic economics practices are still rarely found. Meanwhile, the growth of Islamic economics practices, particularly Islamic financial institutions in Indonesia has experienced a slower speed in the recent years. This situation requires a bigger support from all stakeholders of the ummah, including from the mosques and their community.

As far as the researchers concerned, most mosques have not yet intentionally been dedicated to enhance the Islamic economics practices among Muslim society though they basically have a huge potential to do so. These institutions can potentially be utilized as centers for public education and socialization about Islamic economics and finance concepts as well as for mobilizing and managing the ummah's funds. Therefore, this study investigates to what extent the role of mosques in Banjarmasin in enhancing the Islamic economic practices.

\section{LITERATURE REVIEW}

A mosque is an institution that has strategic and important roles in Islam. It is not only a place for ritual activities, but also a one-stop center for many activities of Muslim society. At the time of the Prophet Muhammad peace be upon him, the mosque was used for learning and teaching, providing assistance for the poor and the needy, adjudicating legal cases, arranging war strategies, welcoming delegates from abroad and others in addition to its traditional role for ritual activities [2][3].

Although most mosques have not yet involved in enhancing the Islamic Economics practices, few mosques in certain locations in Indonesia have already started to play this economic role [4]. These mosques can be made as the models for economic development empowering the ummah. Among those mosques are Jogokaryan Mosque in Yogyakarta, Nurul Jannah Mosque in Gresik, East Java and Wahidiyah Mosque in Kediri, East Java. They involve actively in empowering Muslim society, stimulate their economic condition and improve their welfare through establishing Shariah cooperatives or Baitul Mal wat Tamwil (BMT) and supporting local small and medium enterprises [5]. Furthermore, Masjid Raya of Pondok Indah sets up a BMT while Masjid Jami' of Bintaro Jaya provides Pinjaman Mikro Masjid (micro loan) to its community [6]. In addition, At-Taqwa Mosque in Bangkalan also channels loans for small enterprises [7].

In order to perform its economic mission, the professionalism of mosque management is a must. There is a significant relationship between the quality of mosque management and its capacity to make the mosque prosperous [8]. Without the professionalism of mosque management, the mission to empower economic status of the ummah would never be achieved successfully [9].

In the context of economic empowerment, mosque management in Malaysia shows a surprising record. Razak, Hussin, Muhammad and Mahjom (2014) reported that out of 
137 mosques in 3 regions of Perak, collected a big amount of ummah's cash fund, i.e. around RM 11,461,151 or equivalent to $\mathrm{Rp} 40$ billion throughout 2009-2011. Those mosques also have a variety of fixed assets that provide monthly earnings apart from zakat, infaq or waqf, such as buildings and rooms to rent, rice fields and plantation, shares in various companies, and many more [10].

Meanwhile, various studies indicated the low level of understanding about the Islamic Economics concept and practices among Indonesian Muslim community. The lack of public education and socialization seems to become one of the main causes behind this condition [11][12]. With regard to the role of mosque, Mingka (2011) revealed that mosques in general still play a limited role in educating Muslim people about the Islamic Economics concept while in fact this program is highly important [13].

Alamsyah (2012) highlighted that one of the key factors to expand the performance of Islamic financial industry, both in funding and financing, is public education [11]. The better understanding Muslim people have about the Islamic Economics concept, the bigger chance they become loyal consumers to this industry [12]. Furthermore, an effective, attractive and adaptive socialization through numerous media and channels are highly necessary. Improving the roles of government, religious leaders, public figures in boosting Muslim understanding, and awareness about Islamic economic concept are also equally important to be done [14].

\section{RESEARCH METHOD}

\section{A. Type of Research}

This study constitues a quantitative research using descriptive statistic that depicted the role of mosques as well as the perception of mosques management and community in enhancing the Islamic economic practices.

\section{B. Population and Sample}

The population of this study was mosques located in Banjarmasin, the capital city of South Kalimantan province. Based on the data from the website of SIMAS (Sistem Informasi Masjid), Ministry of Religious Affairs (MORA), there are currently 191 mosques in the city. This study subsequently selected 25 mosques to be sample where the representation level was $13.1 \%$.

The method for sample selection used in this study was purposive sampling considering the sub-discrict (kecamatan) representation, characteristics of worship, mosque size as well as number of mosque community. Heads of mosque management or his substitute was the one who provided the data about the profiles and programs of the mosques. Then, approximately 5 persons of mosque management and 10 persons of mosque community were selected to fill in the questionnaire about the perception of mosque management and community using convenient sampling method.

\section{Collecting Data Method and Technique of Analysis}

The survey method was chosen for collecting data by means of questionnaire containing close and open questions. There were 3 types of questionnaires in this study, i.e. This research was funded by the Ministry of Research, Technology and Higher Education, Republic of Indonesia, with the scheme of Penelitian Produk Terapan (Applied Product Research), 2017.
Questionnaire A about mosque profiles and programs, Questionnaire B about perception of mosque management, and Questionnaire C about perception of mosque community .

Prior to data collection, the draft of questionnaires were spread through focus group discussion (FGD) involving academics and mosque management. The data were analyzed using SPSS version 21.

\section{RESULTS}

The data of this study were gathered from survey. The data consist of 2 types: data about the mosques and the perception of mosque management and community.

\section{A. Demographic profiles of the mosques}

There were 25 mosques chosen as sample in this study; the mosques were located throughout Banjarmasin (Table 1). Based on the table, most mosques (40\%) were built during 1981-2000 followed by those built in 1946-1980 (28\%), and the rest (20\%) were built after 2000. The oldest mosque is the Great Mosque (Masjid Jami') of Sungai Jingah which was built in 1777 . Regarding to the mosque size, $26 \%$ out of the total mosques has the size between $500-1,000 \mathrm{~m}^{2}$, followed by $24 \%$ with the size from $1,001-2,500 \mathrm{~m}^{2}$ and another $24 \%$ with the size above $5,000 \mathrm{~m}^{2}$.

In terms of the capacity, most mosques (44\%) can accommodate about 500-1,000 people, $28 \%$ accommodates about1,001-3,000 people, while $9 \%$ of the mosques has the capacity for more than 3,000 people. The sampled mosques were located at all sub-regions in Banjarmasin. Furthermore, only one fifth (20\%)of the mosques establish business affairs as part of their activities, while $80 \%$ do not have any business unit at all. The types of business units include shop, cooperative, building rental and space rental for bank ATM, as well as training unit.

\section{B. Demographic profiles of the respondents}

Respondents of this study are mosque management and community. The total respondents are 374, consists of 124 mosque management and 250 mosque community (Table 2).

TABLE I. DEMOGRAPHIC PROFILES OF THE MOSQUES

\begin{tabular}{llrr}
\hline \multirow{2}{*}{ Variable } & \multicolumn{1}{c}{ Category } & Frequency & $\%$ \\
\hline Year established & $<1900$ & 1 & 4 \\
& $1901-1945$ & 2 & 8 \\
& $1946-1980$ & 7 & 28 \\
& $1981-2000$ & 10 & 40 \\
& $>2000$ & 5 & 20 \\
\hline Size & $<500 \mathrm{~m}^{2}$ & 2 & 8 \\
& $500-1, .000 \mathrm{~m}^{2}$ & 7 & 26 \\
& $1,001-2,500 \mathrm{~m}^{2}$ & 6 & 24 \\
& $2,501-5, .000 \mathrm{~m}^{2}$ & 4 & 16 \\
& $>5,000 \mathrm{~m}^{2}$ & 6 & 24 \\
\hline Capacity & $<500$ people & 4 & 16 \\
& $500-1,000$ people & 11 & 44 \\
& $1,001-3,000$ people & 7 & 28 \\
& $>3,000$ people & 3 & 12 \\
\hline Location & North Banjarmasin & 6 & 24 \\
& West Banjarmasin & 3 & 12 \\
& Central Banjarmasin & 5 & 20 \\
\hline
\end{tabular}




\begin{tabular}{llrl}
\hline & East Banjarmasin & 6 & 24 \\
& South Banjarmasin & 5 & 20 \\
\hline Having business & Yes & 5 & 20 \\
unit & No & 20 & 80 \\
\hline
\end{tabular}

TABLE II. DEMOGRAPHIC PROFILES OF THE RESPONDENTS

\begin{tabular}{|c|c|c|c|}
\hline Variable & Category & Frequency & $\%$ \\
\hline \multirow[t]{2}{*}{ Gender } & Male & 341 & 91.2 \\
\hline & Female & 33 & 8.8 \\
\hline \multirow[t]{5}{*}{ Age } & $<30$ years & 92 & 24.6 \\
\hline & $30-40$ years & 48 & 12.8 \\
\hline & $41-50$ years & 69 & 18.4 \\
\hline & $51-60$ years & 84 & 22.5 \\
\hline & $>60$ years & 81 & 21.7 \\
\hline \multirow[t]{5}{*}{ Education } & Primary school & 14 & 3.7 \\
\hline & Junior high School & 22 & 5.9 \\
\hline & Senior high school & 159 & 42.5 \\
\hline & Diploma/undergraduate & 151 & 40.4 \\
\hline & Postgraduate & 28 & 7.5 \\
\hline \multirow[t]{4}{*}{ Work status } & Entrepreneur & 86 & 23.0 \\
\hline & Private & 124 & 33.2 \\
\hline & Government officer & 56 & 15.0 \\
\hline & Other & 108 & 28.9 \\
\hline \multirow[t]{5}{*}{ Income } & $<\mathrm{Rp} 1$ million & 72 & 19.3 \\
\hline & Rp 1-2.5 million & 129 & 34.5 \\
\hline & $\operatorname{Rp} 2.5-5$ million & 129 & 34.5 \\
\hline & Rp 5-10 million & 37 & 9.9 \\
\hline & $>\mathrm{Rp} 10$ million & 7 & 1.9 \\
\hline \multirow{5}{*}{$\begin{array}{l}\text { Presence at } \\
\text { mosque }\end{array}$} & $1-3$ times a week & 31 & 8.3 \\
\hline & 4 - 7 times a week & 47 & 12.6 \\
\hline & 2 times a day & 58 & 15.5 \\
\hline & 3 - 4 times a day & 99 & 26.5 \\
\hline & 5 times a day & 139 & 37.2 \\
\hline \multirow{4}{*}{$\begin{array}{l}\text { Distance of } \\
\text { house from the } \\
\text { mosque }\end{array}$} & $<500$ meters & 243 & 65.0 \\
\hline & 500 meter -1 kilometer & 65 & 17.4 \\
\hline & $1.01-2$ kilometers & 39 & 10.4 \\
\hline & $>2$ kilometers & 27 & 7.2 \\
\hline
\end{tabular}

Table 2 indicates that the majority of respondents are male $(91.2 \%)$. The age of respondents is above 50 years $(45.2 \%)$, $30-50$ years $(33.2 \%)$, and below 30 years $(24.6 \%)$. It means that the mosque management and community are dominated by those with the age above 50 years. In terms of education level, most respondents $(82.9 \%)$ graduated from senior high school and diploma/undergraduate. This shows that the education level of respondents is generally high, even $7.5 \%$ of them are masters and PhDs.

The working status of respondents varies. About $33.2 \%$ of the respondents work in formal private sectors, $23 \%$ are entrepreneurs, and $15 \%$ are government officers. Meanwhile, $28.9 \%$ have no job consisting of the retired, students, and housewives. The income of majority respondents (69\%) range from Rp 1 to 5 millions.

The frequency of presence among respondents at the mosque is different. The highest group are those who come 5 times a day (37.2\%) and followed by those coming 3-4 times a day $(26.5 \%)$. This shows that the majority of the respondents $(63.7 \%)$ may be categorized as practicing Muslims for their consistency to pray in congregation at mosques everyday. Furthermore, $65 \%$ respondents reside less than 500 meters away the mosques, while the remaining respondents stay around 500 meters to 2 kilometers. Amazingly, there were
$7.2 \%$ respondents who stay at more than 2 kilometers away their mosques.

\section{DISCUSSION}

The concept of Islamic Economics and finance has essentially a wide spectrum involving theoretical and practical aspects, fundamental and instrumental principles, legal and fiqhiyah basis, as well as technical and operational features of Islamic financial institutions in the context of contemporary business. The discussion in this study is then focused into 4 aspects, i.e. perception about some basic concepts of Islamic Economics, synergy between mosque and Islamic banking industry, socialization pertaining to the Islamic Economics concepts, and mosque activities in enhancing the Islamic Economics practices.

\section{A. Perception about some basic concepts of Islamic economics}

Regarding to the perception of mosque management and community, this research specifically used 5 indicators, i.e. legality of Islamic bank, distinction of Islamic bank, legal status of interest (bunga bank), product and service quality of Islamic bank, and understanding about terms used in Islamic banking industry.

It was found from the study that most respondents $(87.7 \%)$ had known the existence of Islamic bank. Majority of the respondents $(82.1 \%)$ also recognized that Islamic banks are different from the conventional ones. Concerning the legal status of interest, most respondents $(78.6 \%)$ understood that it is prohibited by Islamic law while $21.6 \%$ were still in doubt or disagreed about its prohibition. This indicates that the prohibition of interest needs to be more socialized to public by using stronger and more convincing argumentation based on Islamic law and Islamic economic theory.

Meanwhile, the perception of respondents about product and service quality of Islamic banks was varied. About $46.8 \%$ stated that the quality of Islamic banks is more or less similar with conventional banks while $53.2 \%$ assumed that the quality of Islamic banks is lower than conventional banks.. In addition, $61.8 \%$ of the respondents stated that the terms used in Islamic banking industry are not easily understood while only $38.2 \%$ of them stated contradictive. These data show that the understanding the terms used in Islamic banking industry still needs more improvement.

TABLE III. PERCEPTION ABOUT SOME BASIC CONCEPTS OF ISLAMIC ECONOMICS

\begin{tabular}{cl|c}
\hline No & \multicolumn{1}{c|}{ Indicator } & $\begin{array}{c}\text { Level of } \\
\text { Agreement }\end{array}$ \\
\hline 1 & $\begin{array}{l}\text { Knowing about the existence of Islamic bank } \\
2\end{array}$ & $\begin{array}{l}\text { Recognizing that Islamic bank is different from } \\
\text { conventional banks }\end{array}$ \\
3 & $\begin{array}{l}\text { Understanding about the prohibition of interest (bunga } \\
\text { bank) according to Islamic law }\end{array}$ & $78.6 \%$ \\
4 & $\begin{array}{l}\text { Having similar quality between Islamic banks and } \\
\text { conventional banks }\end{array}$ & $46.8 \%$ \\
5 & $\begin{array}{l}\text { Understanding about the terms used in Islamic banking } \\
\text { industry }\end{array}$ & $38.2 \%$ \\
\hline
\end{tabular}




\section{B. Synergy between mosque and Islamic banking industry}

The synergy between the mosque and the Islamic banking industry was measured by 6 (six) indicators: ownership of Islamic bank account, financing from Islamic banks received by mosques, cooperation between mosques and Islamic banks, sponsorship or aids from Islamic banks, providing space of ATM (Automatic Teller Machine) for Islamic or conventional banks.

The findings confirmed the current assumption that the synergy and cooperation between mosques and Islamic banks are still categorized as low. The lack of synergy and cooperation between these two institutions is apparently caused by both institutions, not only by the mosque, but also by the Islamic bank industry. This later institution seems not to take advantage yet on the existence of mosque as the central institution in Muslim ummah. The survey showed that $60 \%$ of the mosques have Islamic bank accounts; while financing, cooperation, and sponsorship from Islamic banks to mosques are commonly below $30 \%$.

Regarding to the space of ATM for Islamic or conventional banks, there are 2 (two) mosques (8\%) providing the ATM space for Islamic banks and 3 (three) mosques (12\%) providing the ATM space for conventional banks. The existence of ATMs around the mosques is certainly useful, but when such ATMs are provided for conventional banks, it is essentially contra productive or against the Islamic law. Mosques should contribute to the development of Islamic banks, including providing space of ATMs for them, but should not offer the similar thing for conventional banks. The mosque should not support the conventional banking system that is clearly prohibited by the Islamic law.

\section{Socialization pertaining to the Islamic economic concepts}

The study asked the respondents whether their mosques had delivered special talks on the Islamic Economics and finance. It was found that $42.8 \%$ of the mosques routinely and frequently delivered it while the remaining $57.2 \%$ only delivered it occasionally, rarely or even never. It means, the majority of mosques have not provided sufficient or necessary sessions for Islamic Economics and finance to their communities. This fact is confirmed by [15] in his research on the content of Friday sermons delivered by preachers (khatib or $d a^{\prime} i$ ) in Banjarmasin that was dominated by ibadah (ritual worship) aspects while muamalah (non-ritual worship) aspect such as business, economic, politic, social, and so forth, were not adequately delivered. The limited numbers of Muslim preachers who are expert in Islamic Economics and finance concepts are apparently the reasons behind this fact.

\section{Mosque activities in enhancing the Islamic Economics practices}

The kinds of mosque activities that can be categorized as developing Islamic Economics were obtained from the responses of mosque management and community. They were required to identify what the activities should be undertaken by mosques to enhance the Islamic Economics practices. Table IV describes such activities based on its urgency according to the respondents.
TABLE IV. FURTHER MOSQUE' ACTIVITIES

\begin{tabular}{cl|c}
\hline No & \multicolumn{1}{c|}{ Indicator } & Response \\
\hline 1 & Propose a financing from Islamic banks & $90.4 \%$ \\
2 & Have an account of Islamic bank & $80.5 \%$ \\
3 & Organize regular talks for Islamic economics and & $73.3 \%$ \\
& finance & $41.7 \%$ \\
4 & Manage zakat fund more professionally & $25.7 \%$ \\
5 & Perform special trainings in Islamic economics and & \\
& finance & $17.9 \%$ \\
6 & Set up Shariah cooperative based-mosques & $9.9 \%$ \\
7 & Provide spaces of ATMs for Islamic banks only &
\end{tabular}

The above findings indicate that there are many activities that can be done by a mosque in order to enhance the roles for developing Islamic Economics practices. Some of those activities can be easily done by the mosque itself, such as open up Islamic bank account while other activities require the willingness or mutual intention from Islamic bank industry such as financing, cooperation, and sponsorship from Islamic banks to mosques. In addition, some activities need the support from other parties such as having Islamic economic and finance disciplines at universities, or from relevant organizations in this field such as MES (Masyarakat Ekonomi Syariah), IAEI (Ikatan Ahli Ekonomi Islam), or Fordebi (Forum Dosen Ekonomi dan Bisnis Islam). Meanwhile, in establishing Shariah cooperatives, the consensus from mosque management and community to support it as well as the professionalism in managing it are highly necessary so that it can grow and expand steadily. If mosques as the central institution of the ummah are able to perform these activities professionally, the development of Islamic Economics practices will be significantly accelerated.

\section{CONCLUSION}

From the above discussion, it can be concluded that the role of mosques in enhancing the Islamic Economics practices in Banjarmasin is generally still limited. This can be seen from the lack of understanding on some Islamic Economics concepts especially about the legal status of interest (bunga bank) and terms used in the industry; the low level of synergy and cooperation between the mosques and Islamic banking industry; and the minimum frequency of learning and training about Islamic Economics concepts delivered in the mosques.

For the next, communication and coordination between these institutions must be promoted by intensifying several important activities as highlighted above. Both institutions need to create a better and mutual synergy that enhances the Islamic Economics practices. Furthermore, specific talks on Islamic Economics and finance concepts also need to be conducted more frequently and routinely at mosques because this will improve the understanding among mosque management and community. Eventually, this better understanding will lead to further improvement in the level of synergy between these two important institutions for the ummah. 


\section{REFERENCES}

[1] Bahtiar, Edi. "Mengembalikan Fungsi Masjid Sebagai Sentra Peradaban Umat Manusia," Empirik, vol. 5(2), 2012, pp.33-58.

[2] Frishman, Martin, \& Khan, Hasan-Uddin. The Mosque: History, Architectural Development \& Regional Diversity. New York: Thames \& Hudson, 2002.

[3] Mokhtar, Syaikh Ali Mohamad. Peranan Masjid dalam Islam. Kuala Lumpur: YADIM, 2003.

[4] Rohman, Dudung Abdul. Pemberdayaan Ekonomi Syariah Berbasis Masjid. Retrieved 27 April 2015 http://bdkbandung.kemenag.go.id/ jurnal/271-pemberdayaan-ekonomi-syariah-berbasis-masjid.

[5] Muslim, Azis, Karsidi, Ravik, \& Wijaya, Mahendra. "A Mosque-Based Economic Empowerment Model for Urban Poor Community," Int. J. of Social Science Research, vol. 2(2), 2014, pp. 80-93.

[6] Abshori, Abdul Fikri. Strategi Masjid dalam Pemberdayaan Ekonomi Umat (Studi pada Masjid Raya Pondok Indah dan Masjid Jami Bintaro Jaya). Universitas Islam Negeri Syarif Hidayatullah, Jakarta, unpublished.

[7] Auliyah, Robiatul. "Studi Fenomenologi Peranan Manajemen Masjid At-Taqwa dalam Pemberdayaan Ekonomi Masyarakat Bangkalan," Kompetensi, vol. 8(1), 2014, pp. 74-91.

[8] Wulandari, Sri Lestari. Hubungan Antara Kualitas Pengelolaan Masjid dengan Upaya Memakmurkan Masjid pada Masyarakat Tegalsari Salatiga. (Skripsi), STAIN Salatiga, 2012, unpublished.
[9] Nugraha, Firman. "Aktualisasi Dakwah Bil'amal Berbasis Masjid," Tatar Pasundan, Jurnal Balai Diklat Keagamaan Bandung, vol. 5(13), 2011, pp. 56-62.

[10] Razak, Azila Abdul, Hussin, Mohd Yahya Mohd, Muhammad, Fidlizan, \& Mahjom, Nurhanie, "Economic Significance of Mosque Institution in Perak State, Malaysia," Kyoto Bulletin of Islamic Area Studies, vol. 7,2014, pp. 98-109.

[11] Alamsyah, Halim, "Perkembangan dan Prospek Perbankan Syariah Indonesia: Tantangan Dalam Menyongsong MEA 2015," paper presented at the Milad ke-8 Ikatan Ahli Ekonomi Islam (IAEI), 13 April 2012, Jakarta, unpublished.

[12] Tim-Peneliti. Potensi, Preferensi dan Perilaku Masyarakat terhadap Bank Syariah di Sumatera Barat. Padang: Bank Indonesia Padang dan Lembaga Penelitian Universitas Andalas, 2001.

[13] Mingka, Agustianto, "Peran Masjid dalam Sosialisasi Ekonomi Syariah," 2011. Retrieved 26 April 2015 http://www.agustianto centre.com/? $\mathrm{p}=476$.

[14] Sadhana, Kridawati, "Sosialisasi dan Persepsi Bank Syariah (Kajian Kebijakan Enkulturasi Nilai-nilai Bank Syariah,” Jurnal Keuangan dan Perbankan, vol. 16(3), 2012, pp. 481-488.

[15] Budiman, Mochammad Arif, "Komposisi Materi Dakwah dalam Khotbah Jumat di Kota Banjarmasin,” Intekna, vol. 8(1), 2008, pp. 8087. 